\title{
Dijital Pazarlama Çağında Çevrimiçi Alışverişin Fayda ve Risk Algısı (Benefit and Risk Perception of Online Shopping at Digital Marketing Era)
}

\section{Serhat KARAOĞLAN iD a Tülin DURUKAN iD}

a Kırıkkale Üniversitesi, İ̈BF, İşletme Bölümü, Kırıkkale, Türkiye. serhat@karaoglan.net

b Kırıkkale Üniversitesi, İ̈BF, İşletme Bölümü, Kırıkkale, Türkiye. tdurukan@kku.edu.tr

\begin{tabular}{|c|c|}
\hline MAKALE BİLGİSİ & ÖZET \\
\hline $\begin{array}{l}\text { Anahtar Kelimeler: } \\
\text { Çevrimiçi Alışveriş } \\
\text { Algılanan Fayda } \\
\text { Algılanan Risk }\end{array}$ & $\begin{array}{l}\text { Amaç - Bu araştırma, çevrimiçi alışveriş yapan tüketiciler ile alışveriş yapmayanların ve internet } \\
\text { kullanımı yüksek yoğunlukta olan tüketiciler ile internet kullanımı düşük yoğunlukta olanların } \\
\text { çevrimiçi alışverişte algıladıkları faydalar ve algıladıkları riskler arasında farklılık olup olmadığına } \\
\text { bakılması ve çevrimiçi alışverişin algılanan faydası ile çevrimiçi alışverişin algılanan riski arasındaki } \\
\text { ilişkinin incelenmesi amacı ile gerçekleştirilmiştir. }\end{array}$ \\
\hline $\begin{array}{l}\text { Gönderilme Tarihi } 23 \text { Ekim } \\
2019 \\
\text { Revizyon Tarihi } 6 \text { Nisan } 2020 \\
\text { Kabul Tarihi } 4 \text { Mart } 2020\end{array}$ & $\begin{array}{l}\text { Yöntem - Araştırma, yüz yüze anket yöntemi ile } 448 \text { kişiye yapılmıştır. Araştırmanın ilk bölümü } \\
\text { tanımlayıcı sorulardan, ikinci bölümü ise Forsythe vd. (2006) tarafından hazırlanmışolan "Çevrimiçi } \\
\text { Alışverişin Algılanan Fayda ve Riskleri" ölçeğinden adapte edilen sorulardan oluşmaktadır. } \\
\text { Cronbach Alfa ve Faktör analizlerinin ardından internet kullanımına ve çevrimiçi alışveriş yapma } \\
\text { durumuna ayrılan grupların algıladıkları fayda ve risklerinin ortalamaları arasındaki farklar için t- } \\
\text { testi, algılanan fayda ile algılanan risk arasındaki ilişkinin incelenmesi için de Pearson korelasyon } \\
\text { testi uygulanmıştır. }\end{array}$ \\
\hline $\begin{array}{l}\text { Makale Kategorisi: } \\
\text { Araştırma Makalesi }\end{array}$ & $\begin{array}{l}\text { Bulgular - İnternetten alışveriş yapıyor olmanın çevrimiçi alışverişin algılanan faydasını yükselttiği, } \\
\text { algılanan riskini ise düşürdüğ̈̈ tespit edilmiştir. İnternet kullanımı ise algılanan faydaya pozitif } \\
\text { yönde etki ederken, yüksek yoğunlukta internet kullananlar ile düşük yoğunlukta internet } \\
\text { kullananların algılanan riskleri arasında istatistiksel olarak anlamlı bir fark bulunamamıştır. } \\
\text { Çevrimiçi alısverişin algılanan faydası ve algılanan riski arasında da bir korelasyon tespit } \\
\text { edilememiştir. } \\
\text { Tartışma - Çevrimiçi alışverişin algılanan faydası ve algılanan riski, internet üzerinden alışveriş } \\
\text { yapma eğilimine etki etmektedir. İnternet kullanımının artması, çevrimiçi alışverişin algılanan } \\
\text { faydasını arttırmasına rağmen algılanan riskinde anlamlı bir değişikliğe sebep olmaktadır. } \\
\text { Çevrimiçi perakendeciler ve diğer satıcıların, güvenlik sertifikaları, ürün değişimi, ödeme güvenliği } \\
\text { ve farklı ödeme alternatifleri gibi tüketicilere yönelik riski düşürecek hizmetler sunmaları hem } \\
\text { tüketicilerin hem de satıcıların faydasına olacaktır. }\end{array}$ \\
\hline
\end{tabular}

\begin{tabular}{l}
\hline ARTICLE INFO \\
\hline Keywords: \\
Online Shopping \\
Perceived Benefit \\
Perceived Risk \\
Digital Marketing
\end{tabular}

Received 23 October 2019

Revised 6 April 2020

Accepted 4 May 2020

Article Classification:

Research Article

\section{ABSTRACT}

Purpose - This study has been conducted to determine differences between the perceived benefits and risks of online shoppers and non-shoppers and the perceived benefits and risks of heavy internet users and light internet users. The study also examined the relationship between perceived benefit of online shopping and perceived risk of online shopping.

Design/methodology/approach - The research was made with 448 people by face to face questionnaire method. The first part of the research consists of descriptive questions. The second part is based on "Perceived Benefits and Risks of Online Shopping" scale from Forsythe et al. (2006). After Cronbach's Alpha and Factor analyzes, $t$-test was used for the differences between the averages of perceived benefits and risks of groups allocated to internet use and online shopping, and Pearson correlation test was used to examine the relationship between perceived benefit and perceived risk.

Findings - It was found that online shopping activity increases the perceived benefit and reduces the perceived risk of online shopping. While internet use positively affected perceived benefit, no statistically significant difference was found between perceived risks of heavy internet users and light internet users. There was no correlation between perceived benefit and perceived risk of online shopping.

Discussion - The perceived benefit and perceived risk of online shopping affects the tendency to shop online. The increase in the use of the Internet increases the perceived benefit of online shopping but does not cause a significant change in the perceived risk. If online retailers and other vendors to provide services that reduce risk to consumers, such as security certificates, product exchanges, payment security, and different payment alternatives, both consumers and vendors will benefit. 


\section{Giriş}

İnternet kullanıcı sayısının ve kullanım oranlarının artması, elektronik ticaret pazarının da gün geçtikçe büyümesine sebep olmaktadır. Tüketiciler, evlerinin konforunda alışveriş yapabilmekte, efor harcamadan siparişlerini verebilmekte ve siparişleri de kısa bir zaman sonra adreslerine kadar iletilmektedir. Dünyanın herhangi bir noktasındaki çevrimiçi mağaza veya çevrimiçi hizmet, ağa bağlı olunduğu sürece bir uygulama veya tarayıcıdaki adres uzaklığında bulunmaktadır. Çevrimiçi alışveriş kolaylık, konfor, gizlilik gibi birtakım faydalar sağlarken gerek ürünle ilgili gerekse finansal birtakım riskleri de barındırmaktadır. Tüketiciler için faydaların daha yüksek olması alışveriş yapma eğilimini arttırırken, risk algısının daha yüksek olması da alışverişten kaçınmalarına sebep olabilmektedir.

Tüketicilerin, özellikle mobil cihazlarla ağa bağlanma oranları artmaya başladıkça zaman kavramı daha önemli hale gelmektedir (Kotler, Kartajaya ve Setiawan, 2017: 189). Mobil cihazlar gibi her an ve her yerden alışveriş yapma imkânı sağlayan araçların da tüketicilerin hayatında yer alması ile çevrimiçi alışverişin avantajları zaman içinde artıyor gözükmektedir. Bununla birlikte fiziksel alışveriş ortamında bulunulmuyor olması ürün ve zaman boyutlarında riskler barındırırken, dijital ortam finansal riskleri beraberinde getirebilmektedir. Dijital pazarlama çağı tüketicilerin satın alma alışkanlıklarını değiştirmeye başlaması ile markaların bu değişikliklere adaptasyon sağlaması için birtakım adımlar atmasını gerektirmektedir. Yeni alışveriş deneyimlerine uyum sağlamaya çalışan tüketicileri anlayarak fayda faktörlerini arttırmak ve risk faktörlerini de azaltmak için iyileştirmeler yapmak durumundadır.

Dünya'da olduğu gibi Türkiye'de de e-ticaretin hacmi ve sayısı gün geçtikçe artmaktadır. TÜBİSAD’ın (Bilişim Sanayicileri Derneği) Türkiye'de E-Ticaret 2018 Pazar Büyüklüğü Raporu'na (2019: 11) göre e-ticaret pazarı bir önceki yıla göre \%42 artışla 59,9 Milyar TL'ye ulaşmıştır. Aynı rapora göre çevrimiçi perakende alışverişin toplam perakende alışverişe oranı $\% 4,1^{\prime}$ den $\% 5,3^{\prime}$ e yükselmiştir (TÜBİSAD, 2019: 15). Tüketicilerin e-ticarete olan güveni arttıkça alışveriş oranları da yükselecektir. Geleneksel ticarete göre e-ticarete daha az güven duyulmasının ödemenin teslimattan önce gerçekleşmesi, satıcı ile yüz yüze gelinmemesi, satıcının yükümlülüklerini yerine getirmeyeceği gibi kaygılardan kaynaklanması doğaldır (Kim vd., 2008: 544-545). İnternet teknolojisine adaptasyon, e-ticarette tüketicinin daha fazla güven duymasına sebep olabilecektir. İnternete daha fazla adapte olan tüketici, e-ticaretin faydalarının da daha çok farkına varabilecektir. Dijital pazarlama çağının gelmiş olmasıyla markaların büyüyen e-ticaret pazarında yer almaması, değişen müşteri tercihlerine ve satın alma davranışlarına uyum sağlamaması rekabette geride kalmalarına sebep olacaktır.

\section{Algılanan Fayda ve Algılanan Risk}

Çevrimiçi alışveriş yapma eğilimi internet üzerindeki mağaza/satıcı ve ürünlerden etkilenirken, tüketici güveni bu eğilimi arttırmakta ve algılanan riskler de eğilime negatif yönde etki etmektedir (Pappas, 2015: 92). E-Mağazalarda uzun dönemli başarı için tüketicilerin davranışlarını ve algılarını anlayabilmek önemlidir. Bu nedenle tüketicilerin alışveriş yapmasına etki eden faktörlerin, risk, güven ve fayda algılarının incelenmesi de araştırmacılar ve profesyoneller tarafından üzerinde durulması gereken bir konudur. Sosyal psikoloji, eticaret, bankacılık gibi birçok alanda incelenmiş olan güven kavramı, bir kişinin çoğunlukla önceki etkileşimlerine dayanan gelecekteki davranışı hakkındaki beklentisi olarak ifade edilebilir (Roca vd., 2009: 98).

E-ticarete olan güvenin artması için tüketicilerin algıladığı faydanın yükselmesi, algıladığı riskin azalması gerekmektedir. Çevrimiçi alışverişteki soyutluk, geleneksel alışverişe göre güvenin ve risk algısının önemini arttırmaktadır. E-ticarette tüketicinin, kontrolü tamamen çevrimiçi satıcıya bırakmış olması; alışverişin gerçekleştirilebilmesi için çevrimiçi alışverişin yanı sıra e-satıcıya olan güvenin yüksek olması gerekliliğini göstermektedir. Ayrıca algılanan faydayı arttıracak keyif ve eğlence unsurları da çevrimiçi alışveriş yapılan sitenin içeriğine, tasarımına vb. göre değişebilecektir.

Bauer (1960), tüketici davranışları bağlamında riski, tüketicinin gördüğü belirsizlik olarak tanımlamıştır. Bu ilk tanımlamanın ardından algılanan risk ile ilgili uzunca süredir teorik açıklamalar yapılmaya çalışılmış ve bu açıklamalar nitel ve nicel çalışmalarla desteklenmiştir. Böylelikle, algılanan risk, tüketici davranışındaki en önemli itici güçlerden biri olarak kabul edilmiştir (Hong, 2015: 323). Tüketicinin algılanan riski sosyal risk, finansal risk, fiziksel risk, performans riski, zaman riski ve psikolojik risk olarak 6 tipte görülmektedir (Mitchell, 1992: 27). 


\section{S. Karaoğlan - T. Durukan 12/2 (2020) 1072-1082}

Alışveriş rahatlığı (kolaylığı), tüm alışveriş sürecini kapsayan çok boyutlu bir yapı olarak tüketicinin zamandan ve emekten kaçınmasının algılanma derecesi olarak tanımlanmaktadır (Brown, 1990: 54-55). Kolaylık, çevrimiçi satın alma kararlarını etkileyen en önemli motivasyon kaynaklarından biri olmuştur. Tüketicilerin rahatlık arzusu artmış, alışverişe daha az zaman ayırmak istemeye başlamışlar ve böylelikle dikkatleri alternatif bir ortam olarak sanal alışverişe yönelmiştir (Jiang vd, 2013: 191-192). Bu çalışmada alışveriş rahatlığı faktörü ev içi mahremiyet, evden çıkmadan diğer bir ifadeyle bir mağazaya gitmeden alışveriş yapma, zaman sınırı olmadan alışveriş yapma ve mağazayı gezmeme kolaylığı maddeleri ile ölçülmeye çalışılmıştır.

Forsythe vd. (2006) göre ürün seçimi faydası, çevrimiçi alışveriş sayesinde herhangi bir yerdeki ürüne ulaşabilme, ürünler hakkında iyi bilgilere çevrimiçi ulaşabilme, çevrimiçi alışverişte geniş ürün yelpazesi bulunması ve çevrimiçi olarak çok fazla sayıda markaya ve perakendeciye erişilebilme şansı maddeleri ile ölçülerek çevrimiçi alışverişin faydasına etki etmektedir. Geniş ürün yelpazesine erişim imkânı bulunması ve ürünler hakkında açıklayıcı bilgilerin yer almasının, tüketicinin satın alma kararında önemli ölçüde etkili olduğu görülmektedir (Forsythe vd., 2006: 60-61).

Çevrimiçi alışverişin konforu ise geleneksel alışverişte yer alan; hizmet almak için bekleme, bazı müşterilerin rahatsız hissetmesine sebep olan satış temsilcisi tarafından yardım edilmesi, satın alma gerçekleşmediğinde oluşan mahcubiyet ve sıra bekleme vb. meşguliyet durumlarının olmamasıdır.

Çevrimiçi alışverişin keyif boyutu, yeni bir deneyim olması, ürünleri özelleştirebilme gibi seçeneklerin sunulması, ürün reklamlarının ekranda görüldükten sonra satın alma işleminin gerçekleştirilebilmesi, ürünün sipariş gerçekleştikten sonra müşteriye teslim edilmesi heyecanı unsurlarından oluşmaktadır.

Finansal risk, temel olarak ürünün performansının yetersiz olması durumunda üründen tam verim almak için harcanan para veya paranın boşa gitmesi olarak tanımlanmaktadır (Mitchell ve Greatorex, 1993: 187-188). Çevrimiçi mağazanın güvenlik ipuçları kullanması (Van Noort vd., 2008) ve mağaza imajının uygun olması halinde algılanan finansal riskin düşmesi mümkün olacaktır (Aghekyan-Simonian vd., 2012: 326-327). Satın alınan ürünün ulaşmaması, yanlışlıkla başka bir ürünün satın alınması, yanlış ürün gelmesi ve fazladan ücret ödenebilmesi finansal risk faktörünün ürünle ilgili kısmını oluştururken; çevrimiçi firmaya güven duyulmaması, kişisel bilgilerin korunmaması ve kredi kartının güvende olmaması güvenlik ve gizlilik kısmını oluşturmaktadır.

Ürün riski, fiziksel olarak temas kurulmayan bir ürünün, dijital ekran üzerinden görülerek satın alınması ile oluşabilecek problemleri ifade etmektedir. Gerçek ürünün test edilemiyor olması, kıyafetlerde oluşabilecek beden ve deneyememe problemi, ürüne dokunamama durumu ve ürünün teslimatında oluşabilecek gecikmeler faktörün maddelerini oluşturmaktadır. Ürün riski, ürün kalitesinin alışveriş yapanlar tarafından çevrimiçi olarak doğru bir şekilde değerlendirememesi nedeniyle istenmeyen bir ürün seçiminden doğacak sonucu göstermektedir (Forsythe ve Shi, 2003: 869).

Algılanan zaman riski ise çevrimiçi alışverişte sipariş verme ve satın alma süreçlerinin karmaşasını, ürün görsellerinin geç yüklenmesini ve alışveriş yapılacak doğru siteyi bulmakta harcanacak zamanı kapsamaktadir.

\section{Algılanan Fayda ve Algılanan Risk Üzerine Yapılmış Çalışmalar}

Çevrimiçi alışveriş ile ilgili son yıllarda çok sayıda çalışma yapılmıştır. Çalışmalar tüketicilerin davranışları üzerinde yoğunlaşmaktadır. Türkiye'de de çevrimiçi alışveriş konusunda kayda değer sayıda araştırma bulunmaktadır. Çevrimiçi alışverişteki risk algısı ve fayda algısı konusunun gelişmesine katkıda bulunan daha önceki çalışmalar üzerinde kısaca durmak gerekmektedir.

Teo ve Yeong (2003) tarafından yapılan çalışmada tüketicilerin çevrimiçi alışverişte karar verme süreçlerine odaklanılmıştır. Literatürdeki ilk çalışmalardan biri olan araştırmada algılanan riskin tüketici satın alma sürecine negatif etkisi olduğu görülmüştür. Bir diğer çalışmada ise tüketiciler algıladıkları risklere ve algıladıkları faydaya göre gruplandırılmışlardır (Bhatnagar ve Ghose, 2004). Gruplandırmanın sonucunda, her bir grubun ürün kategorisine göre internet alışverişi tercihlerine bakılmıştır. Chiu vd. (2004) tarafından yapılan çalışmada da hem hazsal hem de faydacı değerlerin çevrimiçi alışverişte tekrar satın alma davranışını pozitif etkilediği, algılanan riskin ise negatif yönde etkilediği tespit edilmiştir. Doolin vd. tarafından (2005) 


\section{S. Karaoğlan - T. Durukan 12/2 (2020) 1072-1082}

yapılan çalışmaya göre de hem algılanan fayda hem de algılanan risk, çevrimiçi alışverişin miktarı ve sıklığı ile anlamlı derecede ilişkili bulunmuştur. Sosyal etkileşimdeki düşmenin de harcama miktarını azalttığı görülmüştür. Başka bir çalışmada ise internet üzerinden alışveriş tecrübesinin çevrimiçi alışveriş niyetine etki eden farklı risk algıları ile ilişkisini incelenmiştir ve teorik model risk algısının ve alışveriş tecrübesinin satın alma niyetine etkisi üzerine kurulmuştur (Dai vd., 2014). Al-Debei vd. (2015) tarafından yapılan çalışmada güven, algılanan fayda, algılanan web sitesi kalitesi ve elektronik ağızdan ağıza pazarlamanın çevrimiçi alışverişe karşı tüketici eğilimine olan etkisi incelenmiştir ve algılanan fayda ve güvenin daha önemli faktörler olduğu sonucuna varılmıştır.

Ulusal literatürde çevrimiçi alışverişin algılanan risk veya algılanan faydası ile ilgili çalışmalara sıklıkla rastlanmaktadır. Bu çalışmalardan öne çıkanlarına kısaca göz atmak gerekirse ilk olarak Algür ve Cengiz (2011) tarafından yapılan çalışmada internet üzerinden alışveriş yapan ve internet üzerinden alışveriş yapmayan tüketicilerin risk ve fayda algılarını araştırılmak istenmiştir. Çevrimiçi alışveriş yapan tüketicilerin çoğunlukla genç ve eğitimli oldukları sonucuna varılmıştır. Çalışmanın sonuçlarına göre finansal risk grubunda yer alan kredi kartı güvenliği ve kimlik bilgilerinin gizliliği, en yüksek risk algısını oluşturmaktadır. Öğretim elemanları üzerinde yapılan bir diğer çalışmada tüketicilerin demografik özellikleri ile çevrimiçi alışveriş sıklığı ve harcama miktarı arasındaki ilişki incelenmiştir ve tüketicilerin demografik özelliklerine göre algıladıkları fayda ve riskler arasında farklılık olup olmadığına bakılmıştır. Genç katılımcıların çevrimiçi alışverişin faydasına dair algılarının daha yüksek olduğu sonucuna varılmış iken cinsiyet ve eğitim düzeyi açısından ise anlamlı bir farklılık görülmemiştir (Özhan ve Altuğ, 2015). Cesur ve Tayfur (2015) tarafından internet alışverişinde algılanan risklerin belirlenmesi amacı ile üniversite öğrencilerine yönelik bir araştırma yapılmıştır ve internet kullanım süresi, çevrimiçi alışveriş sıklığı ve internet üzerinden yapılmış olan alışveriş miktarı ile risk arasında ters yönde ilişki tespit edilmiştir. Yakın tarihli bir araştırma olarak Şen (2019), algılanan risk faktörlerinin çevrimiçi alışverişe karşı tutumu olumsuz yönde etkilediğini dile getirmektedir.

\section{Araştırma Soruları}

Daha önceki araştırmalarda (Dai vd., 2014) desteklendiği üzere sık çevrimiçi alışveriş yapanlar ile nadir çevrimiçi alışveriş yapanlar ve çevrimiçi alışveriş yapmayanların fayda ve risk algıları arasında farklılık olması beklenmektedir. Çevrimiçi alışveriş yapan tüketicinin rahatlık, ürün seçimi, konfor ve keyif olarak alt faktörlere ayrılmış olan çevrimiçi alışverişin faydasını daha yüksek göreceği düşünülmektedir. Ayrıca çevrimiçi alışveriş yaparak belirsizlik algısının önüne geçmiş olan tüketicilerin risk algısının da düşeceği öngörülmektedir. Finansal risk, ürün performansı riski, psikolojik risk ve zaman riski riskinin çevrimiçi alışveriş yapanlarda anlamlı derecede düştüğü görülmüştür (Forsythe ve Shi, 2003). Buna göre hipotez aşağıdaki şekilde kurulmuştur.

$\mathrm{H}_{1}$ : Çevrimiçi alışveriş yapanlar ile çevrimiçi alışveriş yapmayanların algıladıkları fayda ve algıladıkları riskler arasında farklılık vardır.

İnternette geçirilen süre ve internet teknolojilerine adaptasyon, tüketicilerin çevrimiçi alışverişteki risk algısını düşürerek çevrimiçi alışverişteki fayda algısını yükselteceği öngörülmektedir. Sanal ortamın belirsizliği, satıcı ile yüz yüze olmamak gibi unsurlar; yoğun internet kullanımı, sosyal medyadaki iletişim vb. etkileşimler sebebi ile nispeten azalacaktır. Örneğin, Cesur ve Tayfur (2015) tarafından yapılan çalışmada internet kullanım süresinin algılanan riski düşürdüğü sonucuna ulaşılmıştır. Yapılan önceki araştırmalarda çevrimiçi tecrübenin artması risk algısının azalmasına sebep olmaktadır (Forsythe ve Shi, 2003: 872; Bhatnagar ve Ghose, 2004). Tecrübenin yanı sıra internetle ve dijital dünya ile daha fazla temas halinde olan tüketici için risk algısı azalabilecektir. Buna göre;

$\mathbf{H}_{2}$ : İnternette geçirilen süre ile algılanan fayda ve algılanan risk arasında ilişki vardır.

Çevrimiçi alışveriş yapsın veya yapmasın, tüketicilerin çevrimiçi alı̧̧verişte algıladıkları fayda arttıkça risk algısının düsseceği, algılanan risk arttıkça da fayda algısının düşeceği düşünülmektedir.

H3: Çevrimiçi alışverişte algılanan fayda ile algılanan risk arasında negatif yönlü bir ilişki vardır. 


\section{Yöntem}

Araştırmanın evrenini Ankara'da yaşayan 18 yaşından büyük internet kullanıcıları oluşturmaktadır. Evrenin büyüklüğü sebebi olasılıklı örnekleme yöntemleri tercih edilmemiş, bunun yerine kolayda örnekleme yöntemi uygun görülmüş ve bunun için 2019 yılının ilk yarısında Ankara ilinde yüz yüze anketler yapılmıştır.

Anket formu 2 bölümden oluşmakta olup birinci bölüm demografik bilgiler ile internet kullanımı ve internet alışverişine yönelik sorular barındırmaktadır. Anket formunun ikinci bölümü ise Forsythe vd. (2006) tarafından hazırlanmış olan "Çevrimiçi Alışverişin Algılanan Fayda ve Riskleri” ölçeğinden adapte edilmiştir. Ölçekte algılanan fayda ve algılanan risk ana faktörleri; çevrimiçi alışverişin rahatlığı, çevrimi alışverişte ürün seçimi, çevrimiçi alışverişin konforu, çevrimiçi alışverişin keyfi, çevrimiçi alışverişte finansal risk, çevrimiçi alışverişte ürün riski, çevrimiçi alışverişte zaman riski olmak üzere 7 alt faktöre ayrılmıştır. Bu faktörlerden ilk 4'ü algılanan fayda ana faktörünün altında yer alırken, son 3'ü algılanan risk ana faktörünün altında yer almaktadır.

Geçerlilik ve güvenilirlik için Cronbach Alfa ve Faktör analizleri kullanılmıştır. İnternet kullanımına ve çevrimiçi alışveriş yapma durumuna ayrılan grupların algıladıkları fayda ve risklerinin ortalamaları arasındaki farklar için t-testi, algılanan fayda ile algılanan risk arasındaki ilişkinin incelenmesi için de Pearson korelasyon testi uygulanmıştır.

\section{Bulgular}

Araştırmaya toplam 448 kişi katılmış olup katılımcılara ait demografik bilgiler Tablo 1'de verilmiştir.

Tablo 1. Araştırmaya Katılanlara Ait Demografik Bilgiler ( $\mathrm{n}=448)$

\begin{tabular}{|c|c|c|c|c|}
\hline \multirow{2}{*}{$\begin{array}{l}\text { Cinsiyet } \\
\text { Yaş }\end{array}$} & \multicolumn{2}{|c|}{$\begin{array}{c}\text { Kadın } \\
222(\% 49,6) \\
\end{array}$} & \multicolumn{2}{|c|}{$\begin{array}{c}\text { Erkek } \\
226(\% 50,4)\end{array}$} \\
\hline & $18-29$ & $30-39$ & $40-49$ & 50 ve üstü \\
\hline & $312(\% 69,6)$ & $55(\% 12,3)$ & $45(\% 10,0)$ & $36(\% 8,0)$ \\
\hline \multirow{2}{*}{ Eğitim } & İlköğretim & Lise & Ön lisans & Lisans ve üstü \\
\hline & $42(\% 9,4)$ & $95(\% 21,2)$ & $47(\% 10,5)$ & $264(\% 58,9)$ \\
\hline \multirow[t]{2}{*}{ Gelir Seviyesi } & 2000 ve alt1 & $2001-4000$ & $4001-6000$ & 6001 ve üstü \\
\hline & $287(\% 64,1)$ & $112(\% 25,0)$ & $42(\% 9,4)$ & $7(\% 1,5)$ \\
\hline
\end{tabular}

Tablodan da görülebileceği üzere araştırmaya katılanların cinsiyet dağılımı birbirine yakındır. Katılanların 222 'si kadın iken 226'sı erkektir. Ancak yaş gruplarına, eğitim ve gelir seviyelerine göz atıldığında çoğunlukla lisans ve üstü mezunu, yüksek gelir seviyesine sahip olmayan gençlerden oluştuğu görülecektir. Katılımcıların \%58,9'u lisans ve lisansüstü mezunlarından oluşmaktadır. \%89,1 oranındaki yanıtlayıcı ise ortaalt gelir grubuna dahildir. Çevrimiçi alışveriş ile ilgili yapılan bir ankette böylesine bir demografik profilin oluşması normal görülebilecektir.

Katılımcların internet kullanımları ve internet alışverişleri ile ilgili sorulan sorulara verdikleri yanıtlara göre oluşturulan Tablo ve şekil aşağıda görülebilmektedir.

Tablo 2. Araştırmaya Katılanların İnternet Kullanım ve İnternetten Alışveriş Eğilimleri ( $\mathrm{n}=448)$

\begin{tabular}{lccccc}
\hline İnt. Kullanımı & Hiç & $\mathbf{1}$ saatten az & $\mathbf{1 - 3}$ saat & $\mathbf{3 - 5}$ saat & $\mathbf{5}$ saat üstü \\
& $10(\% 2,2)$ & $53(\% 11,8)$ & $148(\% 33,0)$ & $134(\% 29,9)$ & $103(\% 23,0)$ \\
\hline İnt. Alış. Sıklığı (aylık) & Hiç & $\mathbf{1 - 2}$ kere & $\mathbf{3 - 4}$ kere & $\mathbf{5 - 6}$ kere & $\mathbf{7}$ ve üstü \\
& $128(\% 28,6)$ & $228(\% 50,9)$ & $56(\% 12,5)$ & $21(\% 4,7)$ & $15(\% 3,3)$ \\
\hline İnt. Alış. Harcama (aylık TL) & Hiç & $\mathbf{1 0 0 ~ v e ~ a l t ı ~}$ & $\mathbf{1 0 1 - 2 0 0}$ & $\mathbf{2 0 1 - 3 0 0}$ & $\mathbf{3 0 1}$ ve üstü \\
& $128(\% 28,6)$ & $129(\% 28,8)$ & $109(\% 24,3)$ & $45(\% 10,0)$ & $37(\% 8,3)$ \\
\hline
\end{tabular}

Tablo 2'de katılımcıların internet kullanımları, internette alışveriş sıklıkları ve internet alışverişlerindeki aylık harcama miktarları görülmektedir. Katılımcıların yarısından fazlasının günde 3 saat ve daha fazla internet kullandığı ortaya çıkmıştır. Bununla birlikte katılımcıların yaklaşık $1 /{ }^{\prime}{ }^{\prime}$ ü çevrimiçi alışveriş yapmamaktadır. Araştırmaya katılan 448 kişiden 128'i hiç çevrimiçi alışveriş yapmadıklarını, kalan 320 katılımcı ise çevrimiçi 
alışveriş yaptıklarını belirtmişlerdir. Katılımcıların yaklaşık yarısı ayda 1-2 kere ve 200 TL'den az alışveriş yapmaktadırlar. Hiç internet alışverişi yapmayanların alışveriş yapanlara ve sık alışveriş yapanlara göre risk ve fayda algılarını ölçebilmek adına bu katılımcılar çalışma için önemli veri kaynaklarıdır. Analizler yapılırken anketi yanıtlayan ve hiç internet kullanmadığını söyleyen 10 katılımcı, araştırmanın evreninde yer almamaları sebebiyle hesaplamalara dahil edilmemiştir.

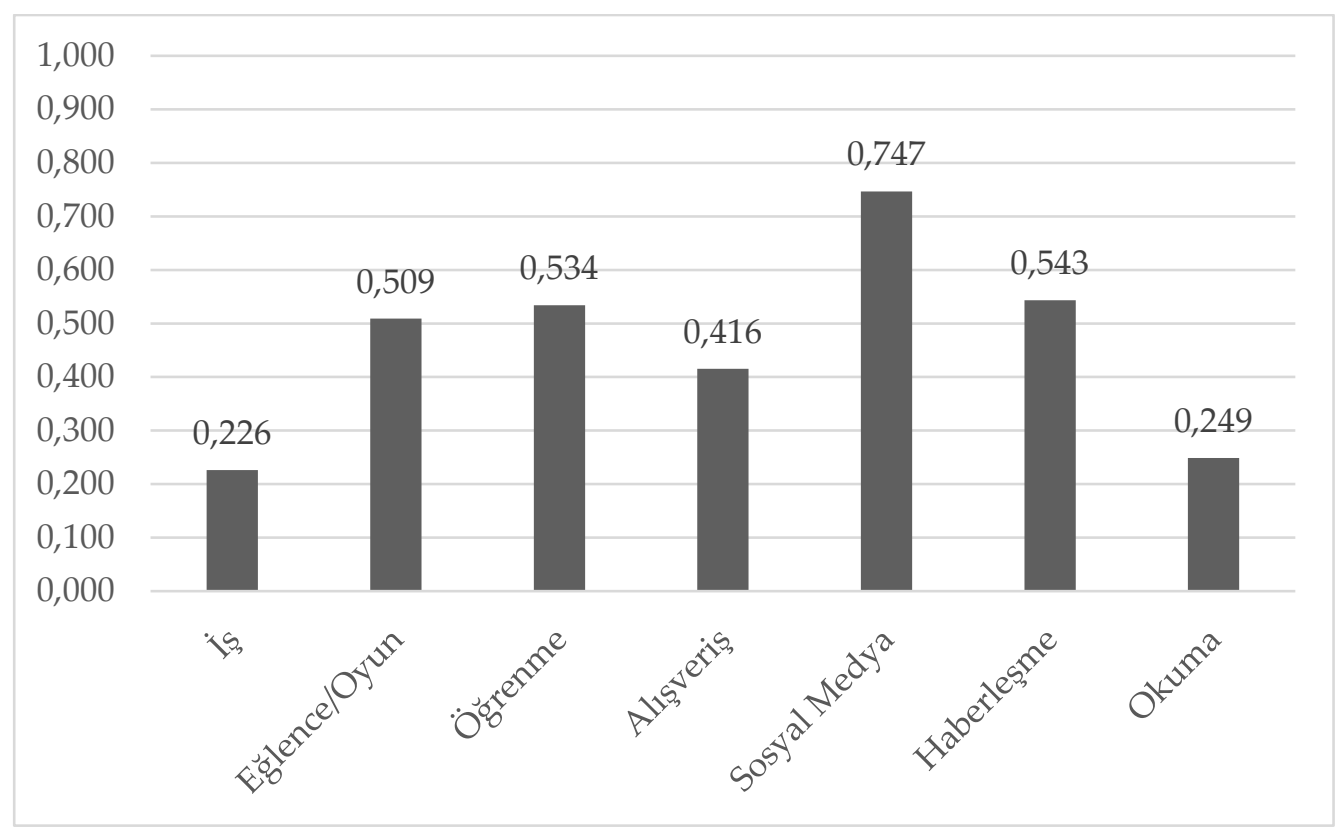

Şekil 1. Katılımcıların İnterneti Genel Kullanma Amaçları

Şekil 1'de çalışmaya katılanların interneti genel olarak hangi amaçla kullandıkları çoklu yanıt alınabilecek şekilde sorulmuştur. Elde edilen verilere göre sosyal medya kullanımı ilk sırada yer almaktadır. Katılımcıların \%74,7'si interneti genel kullanma amaçları içinde sosyal medyayı göstermektedir. Ardından ise sırasıyla ve yakın oranlarla haberleşme, öğrenme ve eğlence/oyun gelmektedir. İnterneti genel kullanma amaçları arasında alışveriş olan katılımcıların oranı ise \%41,6 olarak görülmüştür. İş ve okuma ise sırasıyla \%22,6 ve $\% 24,9$ ile en düşük oranlarda kullanım amacı olarak görülmüştür. Araştırmaya katılanların çoğunlukla genç ve yüksek eğitim seviyesine sahip gruplardan oluştuğu görüldügü için bu bulgu düşündürücüdür.

Çevrimiçi Alışverişin Algılanan Fayda ve Riskleri bölümü, 16'sı algılanan faydayı, 16'sı ise algılanan riski ölçmek üzere tasarlanmış 32 sorudan oluşmaktadır. Algılanan fayda bölümünde 4 soru çevrimiçi alışverişin rahatlığını, 4 soru çevrimi alışverişte ürün seçimini, 4 soru çevrimiçi alışverişin konforunu ve 4 soru da çevrimiçi alışverişin keyfini ölçmeyi amaçlamaktadır. Algılanan risk bölümünde ise 7 soru finansal riski, 6 soru ürün riskini ve 3 soru da zaman riskini ölçmektedir.

32 sorudan oluşan ve 5'li likert ile ölçülen bu bölüme öncelikle faktör analizi uygulanmıştır. Faktör analizi sonucunda "Kargo ücreti" maddesinin faktör yükü, ürün riski faktörü için 0,377; zaman riski faktörü için ise 0,384 olarak hesaplanmıştır. Farkın $0,1^{\prime}$ den düşük olması ve de faktör yüklerinin düşüklügü sebebi ile madde ölçekten çıkarılmıştır. "Ürün gelmesi için bekleme” maddesinde ise faktör analizi sonucunda 0,441 ile düşük bir değer elde edilmiştir ve devamında yapılan güvenilirlik analizi sonucunda ölçekten çıkarılmasına karar verilmiştir. Kalan 30 madde tekrar analiz edildiğinde 7 faktöre ayrılmıştır. Analize göre KMO (Keiser-MeyerOlkin Yeterliliği) değeri 0,877 bulunmuştur ve bu değer bize faktör analizinin yapılabilirliğini ve örneklem sayımızın yeterli olduğunu göstermektedir. Açılanan varyans 7 faktör sonucunda \%63,662 olarak elde edilmiştir.

Ölçeğin güvenilirliğini ölçmek için Cronbach Alfa değerleri hesaplanmıştır. Alfa değeri, ölçekte kalan 30 madde için 0,827; algılanan fayda bölümünde yer alan 16 madde için 0,869 ve algılanan risk bölümünde yer alan 15 madde için ise 0,878 olarak elde edilmiştir.

Ölçekte yer alan maddelerin faktör yükleri ve her bir faktörün Cronbach Alfa değeri Tablo 3'te verilmektedir. 
S. Karaoğlan - T. Durukan 12/2 (2020) 1072-1082

Tablo 3. Faktör ve Güvenilirlik Analizi Sonuçları

\begin{tabular}{|c|c|c|}
\hline Fayda ve Riskler & Faktör Yükleri & Cronbach Alfa \\
\hline A-Rahatlık & & 0,810 \\
\hline A1 & 0,730 & \\
\hline $\mathrm{A} 2$ & 0,764 & \\
\hline A3 & 0,708 & \\
\hline $\mathrm{A} 4$ & 0,657 & \\
\hline B-Ürün Seçimi & & 0,845 \\
\hline B1 & 0,759 & \\
\hline B2 & 0,749 & \\
\hline B3 & 0,749 & \\
\hline B4 & 0,729 & \\
\hline C-Konfor & & 0,803 \\
\hline $\mathrm{C} 1$ & 0,727 & \\
\hline $\mathrm{C} 2$ & 0,779 & \\
\hline $\mathrm{C} 3$ & 0,675 & \\
\hline $\mathrm{C} 4$ & 0,727 & \\
\hline D-Keyif & & 0,658 \\
\hline D1 & 0,685 & \\
\hline D2 & 0,771 & \\
\hline D3 & 0,648 & \\
\hline D4 & 0,618 & \\
\hline E-Finansal Risk & & 0,861 \\
\hline E1 & 0,683 & \\
\hline E2 & 0,774 & \\
\hline E3 & 0,536 & \\
\hline E4 & 0,795 & \\
\hline E5 & 0,738 & \\
\hline E6 & 0,754 & \\
\hline E7 & 0,554 & \\
\hline F-Ürün Riski & & 0,866 \\
\hline $\mathrm{F} 1$ & 0,743 & \\
\hline F2 & 0,839 & \\
\hline F3 & 0,861 & \\
\hline F4 & 0,746 & \\
\hline G-Zaman Riski & & 0,747 \\
\hline G1 & 0,761 & \\
\hline G2 & 0,732 & \\
\hline G3 & 0,706 & \\
\hline
\end{tabular}

Faktör analizinin yapılması ve cronbach alfa değerlerinin hesaplanmasının ardından araştırma hipotezlerinin test edilmesi aşamasına geçilmiştir. Öncelikle çevrimiçi alışveriş yapan ve çevrimiçi alışveriş yapmayan internet kullanıcılarının, çevrimiçi alışverişe dair risk algıları ve fayda algıları arasında farklılık olup olmadığına bakılmıştır. Buna göre internet kullanan ancak internet alışverişi yapmayan 118 yanıtlayıcı ile internetten alışveriş yaptığını belirten 320 yanıtlayıcının algılanan risk ve algılanan fayda skorlarının ortalamaları karşılaştırılmak istenmiştir ve t-testi uygulanmıştır. Alışveriş yapanlar ve alışveriş yapmayanlar olmak üzere ayrılmış olan iki grubun her iki faktör için ortalamaları, standart sapmaları, standart hata ortalamaları, t-testi anlamlılık değerleri ile birlikte aşağıda yer alan Tablo 4'te verilmektedir. 
Tablo 4. İnternetten Alışveriş Yapan ve Yapmayanların Algılanan Fayda ve Algılanan Riskleri

\begin{tabular}{llccccc}
\hline Faktör & Grup & $\mathbf{( n = 4 3 8 )}$ & Ortalama & Std. Sapma & Std Hata Ort & Sig. \\
\hline \multirow{2}{*}{ Algılanan Fayda } & Alışveriş Yapanlar & 320 & 3,8244 & 0,53253 & 0,02977 & \multirow{2}{*}{0,000} \\
& Alş̧veriş Yapmayanlar & 118 & 3,2500 & 0,68942 & 0,06347 & \\
\hline \multirow{2}{*}{ Algılanan Risk } & Alşveriş Yapanlar & 320 & 3,5757 & 0,63266 & 0,03537 & \multirow{2}{*}{0,000} \\
& Alısveriş Yapmayanlar & 118 & 3,8977 & 0,74134 & 0,06825 & \\
\hline
\end{tabular}

Yapılan t-testi sonucunda her iki ana faktör için de anlamlılık değerleri 0,000 çıkmıştır. Ortalamalar incelendiğinde internetten alışveriş yaptığını söyleyen grubun internetten alışveriş yapmayan gruba göre çevrimiçi alışverişe dair fayda algılarının yüksek olduğu, risk algılarının da düşük olduğu söylenebilecektir. $\mathrm{Bu}$ durumda $\mathrm{H}_{1}$ hipotezi kabul edilmiştir. 7 alt faktör karşılaştırıldığında Tablo 5'teki veriler elde edilmektedir.

Tablo 5. İnternetten Alışveriş Yapan ve Yapmayanların Faktörlere Ait İstatistikleri

\begin{tabular}{|c|c|c|c|c|c|c|}
\hline Faktör & Grup & $(n=438)$ & Ortalama & Std. Sapma & Std Hata Ort & Sig. \\
\hline \multirow{2}{*}{ Rahatlık } & Alışveriş Yapanlar & 320 & 4,1422 & 0,77864 & 0,04353 & \multirow{2}{*}{0,000} \\
\hline & Alışveriş Yapmayanlar & 118 & 3,3689 & 0,90918 & 0,08370 & \\
\hline \multirow{2}{*}{ Ürün Seçimi } & Alışveriş Yapanlar & 320 & 4,0023 & 0,75676 & 0,04230 & \multirow{2}{*}{0,000} \\
\hline & Alışveriş Yapmayanlar & 118 & 3,4216 & 0,94773 & 0,08725 & \\
\hline \multirow{2}{*}{ Konfor } & Alışveriş Yapanlar & 320 & 4,0734 & 0,78838 & 0,04407 & \multirow{2}{*}{0,000} \\
\hline & Alışveriş Yapmayanlar & 118 & 3,5487 & 0,95534 & 0,08795 & \\
\hline \multirow{2}{*}{ Keyif } & Alışveriş Yapanlar & 320 & 3,0797 & 0,76353 & 0,04268 & \multirow{2}{*}{0,000} \\
\hline & Alışveriş Yapmayanlar & 118 & 2,6610 & 0,75992 & 0,06996 & \\
\hline \multirow{2}{*}{ Finansal Risk } & Alışveriş Yapanlar & 320 & 3,3643 & 0,80611 & 0,04506 & \multirow{2}{*}{0,000} \\
\hline & Alışveriş Yapmayanlar & 118 & 3,7906 & 0,86397 & 0,07953 & \\
\hline \multirow{2}{*}{ Ürün Riski } & Alışveriş Yapanlar & 320 & 4,2727 & 0,74283 & 0,04153 & \multirow{2}{*}{0,986} \\
\hline & Alışveriş Yapmayanlar & 118 & 4,2712 & 0,90143 & 0,08298 & \\
\hline \multirow{2}{*}{ Zaman Riski } & Alışveriş Yapanlar & 320 & 2,9063 & 0,93029 & 0,05200 & \multirow{2}{*}{0,000} \\
\hline & Alışveriş Yapmayanlar & 118 & 3,6497 & 0,88444 & 0,08142 & \\
\hline
\end{tabular}

Tablo 5'ten de görülebileceği üzere çevrimiçi alışverişin algılanan faydasını oluşturan rahatlık, ürün seçimi, konfor ve keyif faktörlerinin hepsinde çevrimiçi alışveriş yapanlar ile çevrimiçi alışveriş yapmayanların ortalamaları arasında istatistiksel olarak anlamlı farklılık tespit edilmiştir. Ortalamalar incelendiğinde ise bu anlamlı farklılığın fayda yönünde olduğu anlaşılmaktadır. Buradan da tüketicilerin çevrimiçi alışveriş̧ yaptıkça, konu hakkındaki fayda algılarının olumlu yönde arttığı çıkarımında bulunulabilecektir. Çevrimiçi alışverişin algilanan risk bölümünü oluşturan faktörlerden finansal risk ve zaman riskinde de internet üzerinden alışveriş yapanlar ve yapmayanlar arasında istatistiksel olarak anlamlı farklılıklar tespit edilmiştir. $\mathrm{Bu}$ faktörlerdeki ortalamalar incelendiğinde de çevrimiçi alışveriş yapanların, çevrimiçi alışveriş yapmayanlara göre risk algısının daha düşük olduğu görülmektedir. Ancak algılanan ürün riski faktöründe çalışmaya katılan çevrimiçi alışveriş yapan tüketiciler ile yapmayanlar arasında istatistiksel olarak anlamlı bir farklılık saptanmamıştır. Gerçek ürünü test edememe, kıyafetlerde beden problemi olabilmesi, kıyafetleri çevrimiçi olarak denenememesi, ürüne dokunma ve hissetme ihtimalinin olmaması maddelerinden oluşan ürün riski faktörü tüketici grupları için farklılık içermemektedir. Ortalamalar incelendiğinde bu risk faktörünün diğer risk faktörlerine göre katılımcılar için daha yüksek olduğu da görülmektedir.

İnternet kullanımının daha yüksek çevrimiçi entegrasyon olduğu düşünüldüğünde internette harcanan zamanın çevrimiçi alışverişin algılanan fayda ve algılanan riski için farklılık doğuracağı düşünülmektedir. Bu hipotezi test etmek için yapılan analiz Tablo 6'da verilmiştir.

Tablo 6. İnternette Geçirilen Süreye Göre Algılanan Fayda ve Algılanan Risk Ortalamaları

\begin{tabular}{llccccc}
\hline Faktör & Grup & $\mathbf{( n = 4 3 8 )}$ & Ortalama & Std. Sapma & Std Hata Ort & Sig. \\
\hline \multirow{2}{*}{ Algilanan Fayda } & İnternet kullanımı $\geq 1$ sa. & 385 & 3,7125 & 0,59389 & 0,03027 & \multirow{2}{*}{0,000} \\
& İnternet kullanımı <1 sa. & 53 & 3,3585 & 0,79956 & 0,10983 & \\
\hline \multirow{2}{*}{ Algilanan Risk } & İnternet kullanımı $\geq 1$ sa. & 385 & 3,6102 & 0,67385 & 0,03434 & \multirow{2}{*}{0,195} \\
& İnternet kullanımı $<1$ sa. & 53 & 3,7399 & 0,74377 & 0,10217 & \multirow{2}{*}{}
\end{tabular}




\section{S. Karaoğlan - T. Durukan 12/2 (2020) 1072-1082}

Yapılan t-testi sonucunda algılanan fayda faktöründe internet kullanım süresinin istatistiksel olarak anlamlı bir fark meydana getirmesine karşılık çevrimiçi alışverişin algılanan riskinde anlamlı bir farklılık görülmemektedir. Bu durumda, internet kullanımı arttıkça ve tüketici internet dünyasında derinleştikçe, dijital çağın kolaylıkları, rahatlığı gibi fayda faktörleri konusunda algısı artmakta, risk faktörleri konusunda ise herhangi bir değişiklik olmadığı şeklinde yorumlamak mümkündür. $\mathrm{H}_{2}$ hipotezi kısmi olarak kabul edilmiştir.

Son hipotezi test etmek amacıyla çevrimiçi alışverişin algılanan faydası ile çevrimiçi alışverişin algılanan riski arasındaki korelasyonu ifade eden korelasyon analizi sonuçları Tablo 7'de verilmektedir.

Tablo 7. Algılan Fayda ve Algılanan Risk Arasındaki Korelasyon

\begin{tabular}{lcc}
\hline & Algılanan Fayda & Algilanan Risk \\
\hline Algllanan Fayda & 1 & $-0,077$ \\
Algilanan Risk & $-0,077$ & 1 \\
\hline Sig. $=0,115$ & &
\end{tabular}

Sig. $=0,115$

Yapılan pearson korelasyon testi sonucunda anlamlılık 0,107 olarak bulunmuştur ve bu değer çevrimiçi alışverişin algılanan faydası ile çevrimiçi alışverişin algılanan riski arasında bir ilişki olmadığını göstermektedir. Bu sonuca göre, algılanan fayda arttıkça, algılanan risk düşmemektedir. Dolayısıyla $\mathrm{H}_{3}$ hipotezi reddedilmiştir.

\section{Sonuç}

Bu çalışmada çevrimiçi alışverişin algılanan faydası ve algılanan riski hakkında birtakım bilgiler elde edilmeye çalışılmıştır. Elde edilen bulgulara göre daha önceden çevrimiçi alışveriş yapmanın, sanal belirsizliği ortadan kaldırdığını ve çevrimiçi alışverişin faydalarının daha fazla hissedilmesine sebep olduğu düşünebilecektir. Ayrıca algılanan faydanın alt faktörlerini oluşturan rahatlık, ürün seçimi, konfor ve keyif faktörlerinin tamamında daha önceden çevrimiçi alışveriş yapanları algısı, çevrimiçi alışveriş yapmayanlara göre yüksek çıkmıştır. Algılanan riski oluşturan finansal risk ve zaman riski faktörleri de daha önceden çevrimiçi alışveriş̧ yapanlarda anlamlı derecede düşük çıkmıştır. Çevrimiçi alışveriş yaptıkça, çoğunlukla belirsizliğe bağlı risk faktörü olarak görülen sorunların belirsizlikten çıkması ve tüketicilerin güvenlerinin artması şeklinde sonuçlandığı görülmektedir. Ancak ürün riski faktöründe çevrimiçi alışveriş yapanlar ve yapmayanlar arasında anlamlı bir farklılık oluşmamıştır. Forsythe ve Shi (2003) tarafından yapılan çalışmada da 3 gruba ayrılan tüketicilerden yoğun alışveriş yapanların tüm gruplarda risk algısı ortalama alışveriş yapan ve alışveriş yapmayanlara göre daha düşüktür. Ortalama alışveriş yapan grubun ürün riski algısı alışveriş yapmayanlara göre bile yüksek çıkarak çalışmanın sonuçları ile benzerlik göstermektedir. Bu da ürünlerde oluşabilecek beden ve stok problemi ile kalite algısının tüketici grupları için benzer olduğunu çıkarımında bulunulmasını sağlayabilecektir. Bir diğer çalışmada elde edilen finansal risk algısının çevrimiçi alışveriş tecrübesi ile azaldığı sonucu bu araştırma ile benzerlik gösterirken, çevrimiçi alışveriş tecrübesi arttıkça ürün riski algısının düşmesi sonucu ise farklılık içermektedir (Dai vd., 2014).

Çalışmanın bulgularına göre, internette geçirilen zaman çevrimiçi alışverişin algılanan faydasının yükselmesine sebep olmaktadır. Dijital dünyanın günlük yaşamı kolaylaştırıcı, iş yaşamına katkıda bulunan, eğlenmeye, öğrenmeye, iletişime yarayan faydaları vardır. Bu kadar faydalı bir teknoloji ile daha fazla zaman geçiren kişilerin, internet alışverişi faydalarının da yüksek olması beklendiği gibidir. Bununla birlikte, çalışmada internette geçirilen sürenin çevrimiçi alışverişin risk algısı ile ilişkisinin olmadığı görülmüştür. Bu sonuç, fayda algısının internet kullanımı ve daha önceden alışveriş yapma ile ilişkili olduğunu ancak risk algısının sadece çevrimiçi alışveriş deneyimi sonrası düşeceğini göstermektedir. Bhatnagar ve Ghose (2004) tarafından yapılan araştırmada algılanan ürün riskinin internet tecrübesine göre düştüğü bulgusu bu çalışma ile farklılık içermektedir ancak aynı çalışmada algılanan güvenlik riski faktörü ile internet tecrübesi arasında anlamlı bir ilişki bulunamamıştır. Başka bir çalışmada internet tecrübesinin artması ile finansal risk faktörü için ters yönlü anlamlı bir ilişki bulunmuşken, diğer risk faktörleri için ilişki bulunmamaktadır sonucu elde edilmiştir (Forsythe ve Shi, 2003).

Çalışmadaki bir diğer bulgu da çevrimiçi alışverişin algılanan faydası ve algılanan riski arasında bir korelasyon olmaması durumudur. Beklenti, algılanan fayda arttıkça algılanan riskin artacağı yönünde olmasına rağmen bulgular beklenenin dışında gerçekleştiğini göstermektedir. Yine de araştırmadaki diğer 


\section{S. Karaoğlan - T. Durukan 12/2 (2020) 1072-1082}

sonuçlarla karşılaştırıldığında, bu sonucu açklayabilmek mümkündür. Ürün riski faktöründe çevrimiçi alışveriş yapanlar ile çevrimiçi alışveriş yapmayanlar arasında anlamlı farklılık bulunmaması, algılanan risk faktöründe de yoğun internet kullanıcıları ile seyrek internet kullanıcıları arasında anlamlı farklılık bulunmaması bu sonucu meydana getirmiştir.

Çalışma sonuçlarına göre birtakım öneriler getirmek gerekirse; çevrimiçi alışveriş yapanların alışveriş yapmayanlara göre fayda algısının daha yüksek olması, risk algısının da daha düşük olması sebebiyle, çevrimiçi alışverişin faydalarının ve risklerinin internet kullanıcılarına doğru şekilde aktarılması, alışveriş etkinliğini arttırabilecektir. Risk algısının alışverişe etki ettiği düşünüldüğünde, çevrimiçi perakendeciler ve diğer satıcıların, güvenlik sertifikaları, ürün değişimi, ödeme güvenliği gibi konularda tüketicilere riski düşürecek hizmetler sunmaları da çevrimiçi alışverişe eğilimi arttıracak unsurlardandır. İşletmeler, müşterilerin yaşadığı olası olumsuzluklara karşı gerek sosyal medyada gerekse diğer mecralarda etkili çözümler bularak, müşteri memnuniyetine pozitif etkide bulunmaları, çevrimiçi alışverişten kaçınanların entegrasyonu adına olumlu bir adım olacağı düşünülmektedir.

Katılımcılarının çoğunlukla gençlerden ve internet kullanıcılarından oluşması ve kolayda örneklem yoluyla yapılmış olması araştırmanın kısıtını oluşturmaktadır. Bundan sonra yapılacak çalışmalar için bir öneri sunulacak olursa; sadece internet alışverişi yapanlar üzerinde geniş kapsamlı bir araştırma, fayda ve risk algısının; alt faktörleriyle beraber önem derecelerinin görülmesi adına açıklayıcı sonuçlar verebilecektir. Bir diğer öneri ise internet alışverişi yapanlar ile internet alışverişi yapmayanların homojen dağıldığı bir veri seti ile bu çalışmadaki hipotezler test edilip farklılıkları görmek mümkün olabilecektir. Meslek gruplarına göre çevrimiçi alışveriş derinliği ve algılanan fayda ve riskler arasındaki farklılıklara bakılarak farklı sonuçlar elde edilebilir.

\section{Kaynakça}

Aghekyan-Simonian, M., Forsythe, S., Kwon, W. S. \& Chattaraman, V. (2012). The role of product brand image and online store image on perceived risks and online purchase intentions for apparel, Journal of Retailing and Consumer Services, 19(3), 325-331.

Al-Debei, M. M., Akroush, M. N. \& Ashouri, M. I. (2015). Consumer attitudes towards online shopping: The effects of trust, perceived benefits, and perceived web quality, Internet Research, 25(5), 707-733.

Algür, S. \& Cengiz, F. (2011). Türk tüketicilere göre online (çevrimiçi) alışverişin riskleri ve yararları, Journal of Yasar University, 22(6), 3666-3680.

Bauer, R.A. (1960). Consumer Behavior as Risk Taking. In: Hancock, R.S., Ed., Dynamic Marketing for a Changing World, Proceedings of the 43rd. Conference of the American Marketing Association, 389398.

Bhatnagar, A. \& Ghose, S. (2004). Segmenting consumers based on the benefits and risks of Internet shopping, Journal of Business Research, 57, 1352-1360.

Brown, L. G. (1990). Convenience in services marketing, The Journal of Services Marketing, 4(1), 53-59.

Cesur, Z. \& Tayfur, G. (2015). İnternetten alışveriş davranışında algılanan tüketici riskleri: üniversite öğrencileri üzerinde bir araştırma, Electronic Journal of Vocational Colleges, 5(1), 19-33.

Chiu, C.-M., Wang, E. T. G., Fang, Y-H. \& Huang H.-Y. (2014). Understanding customers' repeat purchase intentions in B2C e-commerce: The roles of utilitarian value, hedonic value and perceived risk, Information Systems Journal, 24, 85-114.

Dai, B., Forsythe, S. \& Kwon, W.-S. (2014). The impact of online shopping experience on risk perceptions and online purchase intentions: does product category matter?, Journal of Electronic Commerce Research, $15(1), 13-24$.

Doolin, B., Dillon, S. Thompson, F. \& Corner, J. L. (2005). Perceived Risk, the Internet Shopping Experience and Online Purchasing Behavior: A New Zealand Perspective, Journal of Global Information Management, 13(2), 66-88. 


\section{S. Karaoğlan - T. Durukan 12/2 (2020) 1072-1082}

Forsythe, S., Liu, C., Shannon, D. \& Gardner, L. C. (2006). Development of a scale to measure the perceived benefits and risks of online shopping, Journal of Interactive Marketing, 20(2), 55-75.

Forsythe, S. \& Shi, B. (2003). Consumer patronage and risk perceptions in Internet shopping, Journal of Business Research, 56, 867-875.

Hong, I. B. (2015). Understanding the consumer's online merchant selection process: Theroles of product involvement, perceived risk, and trust expectation, International Journal of Information Management, 35, $322-336$

Jiang, L. (A.), Yang, Z. \& Jun, M. (2013). Measuring consumer perceptions of online shopping convenience, Journal of Service Management, 24(2), 191-214.

Kim, D. J., Ferrin, D. L. \& Rao, H. R. (2008). A trust-based consumer decision-making model in electronic commerce: The role of trust, perceived risk, and their antecedents, Decision Support System, 44, 544564 .

Kotler, P., Kartajaya, H. \& Setiawan, I. (2017). Pazarlama 4.0: Gelenekselden Dijitale Geçiş, çev. Nadir Özata, İstanbul, Optimist Kitap.

Mitchell, V-W. \& Greatorex, M. (1993). Risk Perception and Reduction in the Purchase of Consumer Services, The Service Industries Journal, 13 (4), 179-200.

Mitchell, V-W. (1992). Understanding consumers' behaviour: Can perceived risk theory help?, Management Decision, 30 (3), 26-31.

Özhan, Ş. \& Altuğ, N. (2015). Tüketicilerin demografik özelliklerinin online alışveriş davranışları üzerine etkileri, Ege Akademik Bakış, 15(4), 481-493.

Pappas, N. (2016). Marketing strategies, perceived risks, and consumer trust in online buying behaviour, Journal of Retailing and Consumer Services, 29, 92-103.

Roca, J. C., Garcia, J. J. \& Vega, J. J. (2009). The importance of perceived trust, security and privacy in online trading systems, Information Management \& Computer Security, 17(2), 96-113.

Şen Ö. (2019). Online alışverişte algılanan risk faktörlerinin alışverişe yönelik tutuma etkisinin incelenmesi, International Journal of Scientific and Technological Research, 5(8), 11-24.

Teo, T. S. H. \& Yeong, Y. D. (2003). Assessing the consumer decision process in the digital Marketplace, Omega, $31,349-363$.

TÜBİSAD (2019). Türkiye'de E-Ticaret 2018 Pazar Büyüklügü.

Van Noort, G., Kerkhof, P. \& Fennis, B. M. (2008). The persuasiveness of online safety cues: the impact of prevention focus compatibility of web content on consumers' risk perceptions, attitudes, and intentions, Journal of Interactive Marketing, 22(4), 58-72. 